\title{
Do Intangible Assets and Innovation Orientation Influence Competitive Advantages? A Case Study of SMEs in Indonesia
}

\author{
Setia Iriyanto ${ }^{1}$, Suharnomo $^{2}$, Muhamad Taufik Hidayat ${ }^{3, *}$, Muhammad Anas ${ }^{4}$ \\ ${ }^{1}$ Department of Management, Faculty of Economics, Universitas Muhammadiyah Semarang, Semarang, Indonesia \\ ${ }^{2}$ Department of Management, Faculty of Economics and Business, Universitas Diponegoro, Semarang, Indonesia \\ ${ }^{3}$ Department of Elementary School Teacher Education, Faculty of Teacher Training and Education, Universitas Muhammadiyah \\ Surakarta, Surakarta, Indonesia \\ ${ }^{4}$ Department of Economics, Faculty of Economics and Business, Universitas Muhammadiyah Surakarta, Surakarta, Indonesia
}

Received December 10, 2020; Revised January 28, 2021; Accepted February 24, 2021

\begin{abstract}
Cite This Paper in the following Citation Styles
(a): [1] Setia Iriyanto, Suharnomo, Muhamad Taufik Hidayat, Muhammad Anas, "Do Intangible Assets and Innovation Orientation Influence Competitive Advantages? A Case Study of SMEs in Indonesia," Universal Journal of Accounting and Finance, Vol. 9, No. 1, pp. 105 - 115, 2021. DOI: 10.13189/ujaf.2021.090111.
\end{abstract}

(b): Setia Iriyanto, Suharnomo, Muhamad Taufik Hidayat, Muhammad Anas (2021). Do Intangible Assets and Innovation Orientation Influence Competitive Advantages? A Case Study of SMEs in Indonesia. Universal Journal of Accounting and Finance, 9(1), 105 - 115. DOI: 10.13189/ujaf.2021.090111.

Copyright $\mathrm{C} 2021$ by authors, all rights reserved. Authors agree that this article remains permanently open access under the terms of the Creative Commons Attribution License 4.0 International License

\begin{abstract}
Competition in small and medium-sized businesses (SMEs) is growing in the era of transition. As a result, these advances are putting pressure on the retail sector to find new and efficient solutions to boost retail and customer experience. Meanwhile, in Central Java, Indonesia, there is one specific SME type that is part of the nation's cultural heritage, namely Batik SME. This study aims to determine the effect of Intangible Assets and Innovation Orientation on the Competitive Advantages of Batik SMEs in Central Java, Indonesia. This study's method was an explanatory survey method with a type of decompression-verification study from primary data obtained from Batik SMEs and using PLS SEM in analyzing the data of the book. The results of this study indicate that Intangible Assets with Path coefficient $(\beta)=$ $0.320, \mathrm{P}$ value $<0.001 \quad(<\alpha=0.05)$, and Innovation Orientation with Path coefficient $(\beta)=0.28 \mathrm{P}$ value $<0.038$ $(<\alpha=0.05)$, have a positive effect on Competitive Advantage with coefficient $(\beta)=0.46$, $\mathrm{P}$ value $<0.001(<\alpha$ $=0.05$ ). This result means that the better Intangible Assets would improve the Batik SME Competitive Advantage. Besides, the Orientation owned by Batik SME would increase the Competitive Advantage. Batik SME in Central Java should improve the quality of their Intangible Asset and Innovation Orientation to increase their
\end{abstract}

Competitive Advantage.

Keywords Intangible Assets, Innovation Orientation, Competitive Advantage, SME

\section{Introduction}

Competition in small and medium-sized businesses (SMEs) is growing in the era of transition. For example, technology-based innovation can provide enhanced retail services and an enjoyable shopping experience [1]. As a result, these advances are putting pressure on the retail sector to find new and efficient solutions to boost retail and customer experience. Such inventions will significantly change the shape of SMEs. Demand-pull has mostly been seen as an innovation driver [2-3]. But this increasing technical complexity, coupled with a shorter life cycle of innovations, makes it difficult to make innovation decisions [4].

Many reports also looked at the disruptive factors that influence the market. Concentrating on process management [5], customer engagement in production $[1-2][6]$, and drivers [2][7]. Forecasting future 
technology's performance plays an important role for advertisers in projecting the output of a specific technological expenditure [8]. Similarly, a deep understanding of the disruptive factors that affect the business could provide executives with useful insights into better investment and policy alignment [9].

Nonetheless, while these findings provide a clear picture of the factors driving market innovation in retail environments, they do not empirically validate retail as a highly innovative or low-innovation field. In the same way, they are not seeking to identify the essential growth fields of the sector. Also, Lee et al. [10] highlighted the extent to which the increasing complexity and availability of technological innovation require companies to track a technical change to maintain profitability for the company. Therefore, simple measuring tools are needed to build an understanding of the creative forces in retail and provide new ways for academics and practitioners to compete effectively in a changing context.

Meanwhile, in Central Java, Indonesia, there is one specific SME type that is part of the nation's cultural heritage, namely Batik SME. Batik is a method of printing patterns on cloth using wax and, by translation, it also defines a piece of fabric printed in this way. Almost all regions in Central Java have various characteristics/motives. Certain areas dominate development in the field and batik motifs/types that have been known so far, such as Solo batik motifs in the area around the Surakarta Residency, Pekalongan batik motifs in the area around the Pekalongan residency, Lasem batik motifs in the Rembang Lasem region (Pati Residency), Semarangan Batik Motifs in the Semarang residency area, Magelang Batik Motifs in the Magelang and surrounding regions (Kedu Residency), and Banyumasan Batik Motifs in the Banyumas and the surrounding regions (the Banyumas Residency). Its distribution can at the same time represent 6 (six) regions in Central Java. This study's objective was to examine the effect of intangible assets and innovative orientation toward the competitive advantage of Batik SMEs in Central Java, Indonesia.

\section{Literature Review}

\subsection{SMEs}

According to the Organization for Economic Cooperation and Development (OECD), the characteristics of small and medium-sized businesses reflect the economic trends of the region and the social and cultural dimensions. Such specific patterns are clearly expressed in the different definitions and SME requirements adopted by foreign countries. While some point to the number of employees as their specific criterion for identifying SMEs, others use capital invested. Others use a variation of the number of employees, capital invested, revenue, and business [11].

In spite of the variations in the comparative definitions of SMEs, businesses have certain common characteristics, the most significant of which is that ownership and management are shared by one individual / family [12] and therefore judgments are often discretionary. Second, SMEs require a small capital base, regardless of the industry and the nation in which they are based. Nevertheless, they also struggle to attract growth funds as a remedy to which they have to rely heavily on personal resources.

Thirdly, in fact, the controlling director seldom differentiates their own capital from the company's finances, and this contributes mainly to the inefficiency of many SMEs. Most SMEs work using labor-intensive technologies. Consider it less easy to move from one product line to something radically different; in fact, most SMEs connect their goals closely to the product line than in other topics such as capital usage. In most SMEs, there is less organizational diversity, a higher turnover of employees and a higher ratio of labor investment. Eventually, the cost of business is strong, likely due to low capital costs, lack of business-life partnership with the agent, lack of market knowledge and weak operating prices, among other factors [13].

Law No. 20/2008 concerning Micro, Small and Medium Enterprises in Article 1 states that: (a) Small Business is a productive economic business that stands alone, which is carried out by individuals or business entities that are not subsidiaries or branch companies that are owned, controlled, or become a part either directly or indirectly of Medium Enterprises or Large Enterprises that meet the Business criteria Small as referred to in this Act. (b) Medium Business is a productive economic business that stands alone, which is carried out by individuals or business entities that are not subsidiaries or branch companies that are owned, controlled, or become a part either directly or indirectly with a Small Business or Large Business with a net worth or annual sales results as stipulated in this Law.

\subsection{Competitive Advantage}

The word "competitive advantage" has become popular [14]. Recent competitive advantage literature discussed some of the issues associated with various competitive advantage concepts that have been available in the literature on strategic management since the concept was first introduced [15]. The literature, in particular, tends to equate competitive advantage with the superior performance of the company. Meanwhile some of the other emerging competitive advantage principles are more focused on factors of competitive advantage. For example, wordings such as "benefit" and "value" relate to the competitiveness of companies [16]. In addition, factors such as market position [14], competition obstacles [17], 
company-specific capabilities [18] are related as deciding triggers of competitive advantage. Sigalas and Economou [15] concluded that the issue with these competitive advantage conceptualizations lies in the fact that competitive advantage was originally improperly operationalised. A less-qualified term, i.e. a higher performance category, should not be included in the description of "competitive advantage."

Competitive advantage in the process of Rao and Holt [19], spans four aspects, i.e. improved performance, improved quality, improved productivity or cost savings. Although the aim of Sigalas and Economou [15] was to merge and advocate for a narrow definition of the competitive advantage is welcomed, the competitive advantage of the business should simply be expressed in the financial aspect, i.e. cost leadership as suggested by Porter [14]. In addition, Rao and Holt [19] also allow calculation of other latent variables in the context of improved efficiency, competitiveness and improved quality. It is also well adapted when it comes to technological innovation, which is basically a combination of product innovation and method innovation. In the new empiric analysis, the authors are planning to follow the same four dimensions as suggested by Rao and Holt [19] in order to assess the efficiency of small and medium-sized businesses in terms of the specific benefits obtained following the introduction of enhanced KM practices.

\subsection{Intangible Assets}

Intangible assets are becoming increasingly important for businesses. The main reason for the increased emphasis on intangible assets is the shift from production to a knowledge-based economy, where competitiveness is primarily based on intangibles. Intangible assets are a crucial tool for creating competitive advantages for companies. In businesses that are now becoming more knowledge-based and information-based, intangible assets will account for a significant percentage of the total business value. The concept of intangible assets is not always clearly known [20]. According to Epstein and Mirza [21], intangible assets are non-financial assets with no physical material maintained for use in the manufacturing or supply of goods or services, or for leasing to others, or for administrative purposes that are recognized and controlled by the company as a result of past activities and from which future economic benefits are likely to emerge.

According to the International Accounting Standards Committee (IASC), intangible assets are assets owned by a corporation due to past events and from which future economic benefits are expected to flow to the corporation (IAS 38). Others defined intangibles as human expertise, skills, abilities, and organizational records, technologies, and routines [22]. Intangible words, knowledge assets, and intellectual capital are used interchangeably and are non-physical interest streams (future benefit claims) generated through innovation (discovery), complex organizational structures, or human resource activities. Different groups use different terms to describe a non-physical request to future benefits-knowledge in accounting literature, intelligence assets of economics, and intellectual capital in management and legal literature-but are pointing to the same thing; a non-physical claim to future benefits [23]. Similar to company tangible assets, intangible assets have become essential resources for the growth of business value. Intangible assets are of increasing importance to all types of organizations for organizational value creation processes.

There are two main ways to determine the company's interest: an internal assessment based on its financial statements (such as the balance sheet and income statement) or external valuation based on its market value. These days, the two concepts diverge extensively [24]. Market value is often much more significant for most companies than book value because market value is generated mainly from investments that do not explicitly show the company's balance sheet. The reason for the difference is, among other factors, the intangible properties of the firms, which are not usually included in the financial statements. For example, the importance of customer relationships, employee interactions, or organizational culture cannot be measured on a balance sheet basis [25].

In the current era of the knowledge economy, the value of intangible assets has increased. Of starters, because businesses such as Microsoft or Coca Cola disclose traditional investments on their balance sheets, they compensate for less than $5 \%$ of their total market capitalization. In 1982, a total of US\$ $62.30(62 \%)$ was expended on tangible assets out of every $\$ 100$ invested in US industrial and mining stocks.

\subsection{Innovation Orientation}

As regards research on the innovation orientation of SMEs, the scarcity of resources that is widely attributed to them is a crucial issue; Woschke et al. [26] argue that for SMEs,' resources are often limited, and these constraints may interfere with their innovation capabilities' [26] p.197. Oke et al. [27] and Woschke et al. [26] note that the greater the financial pressures on SMEs, the greater the focus on exploitative innovation. Kammerlander et al. [28] suggest that SMEs are more concentrated on exploration as their capital base grows. In contrast, McDermott and Prajogo [29] note that SMEs are more centered on development as their resource base decreases. Finally, SMEs can improve their productivity by ambidextrous ingenuity [30]. 


\subsection{Gap Analysis}

Despite these past studies, not many of them focused on intangible assets, innovation orientation, and competitive advantages among SMEs in Indonesia. That condition left a gap for more studies to be done in Indonesia.

\section{Materials and Methods}

\subsection{Methods}

This research uses the explanatory research method by using a quantitative approach. According to Sugiyono [31], analysis according to the level of explanation is research that intends to explain the position of the variables studied and the relationship between one variable with another variable.

\subsection{Population and Samples}

The population is a generalization area consisting of objects/subjects with specific qualities and characteristics determined by researchers to be studied and then drawn conclusions [31]. Because the Batik SME group in Central Java is around 1,200 SMEs, this study uses a sample.

A sample is part of the number and characteristics possessed by the population [31]. Suggested suitable sample sizes range from 100-200 respondents [32]. Population characteristics for this research is not known, so the authors chose the Non Probability Sampling technique, which is a sampling technique by not providing equal opportunities for each element or member of the population to be selected as a sample. The authors did coordinate with several stakeholders (SME and Cooperative Regional Department) to reach the sample. There were 200 respondents chosen and interviewed. The data was collected with a questionnaire in June-September 2019.

\subsection{Variables}

Variable is an attribute or nature or value of people, objects, or activities with individual variations determined by researchers to be studied and drawn conclusions [31]. Research variables can be divided into two, namely:

1. Independent variables influence or are the cause of changes or the appearance of the dependent variable.
The independent variables used in this study are Intangible Assets and Innovation Orientation.

2. A dependent variable is a variable that is affected, or that is due to the existence of an independent variable. The dependent variable used in this study is Competitive Advantage.

\subsection{Hypothesis}

Consequently, the authors offer the following hypotheses on the link between intangible assets, innovation orientation, and competitive advantage:

Hypotheses 1:

$\mathrm{H}_{\mathrm{a}}$ : Intangible assets have a positive effect on competitive advantage

$\mathrm{H}_{0}$ : Intangible assets have not a positive effect on competitive advantage

Hypotheses 2:

$\mathrm{H}_{\mathrm{a}}$ : Innovation orientation has a positive effect on competitive advantage

$\mathrm{H}_{0}$ : Innovation orientation has not a positive effect on competitive advantage

\section{Result}

\subsection{Descriptive Analysis of Respondents}

Descriptive data displays a general description of respondents' answers in the questionnaire. Based on the responses of 200 respondents regarding the variables, the authors described in detail the respondents' answers, which were grouped in descriptive statistics. The range of answers to each variable's question dimensions was determined using the three-box criteria (three-box method) [33]. For ease of interpretation, the answer range was converted to 100 . For this condition, the range of answers starts from 15 to 100 , where the range that occurs was 85 . Furthermore, the range that occurs was divided by three and produced a range of 28.33 , which be used as the basis for interpreting the index value, namely:

- Index value $15.00-43.33=$ Low interpretation

- Index value 43.34 - $71.67=$ Medium interpretation

- Index values $71.68-100=$ High interpretation 
Table 1. Index of Variables

\begin{tabular}{|c|c|c|c|c|c|c|c|c|c|}
\hline \multirow[t]{2}{*}{ No } & \multirow[t]{2}{*}{ Indicator } & \multicolumn{7}{|c|}{ Technological Capital Index } & \multirow[t]{2}{*}{ Index } \\
\hline & & 1 & 2 & 3 & 4 & 5 & 6 & 7 & \\
\hline 1 & Product development guidelines & 0 & 2 & 2 & 5 & 5 & 122 & 64 & 88.21 \\
\hline 2 & Technical knowledge of special product manufacturing & 1 & 2 & 3 & 13 & 16 & 105 & 60 & 85.42 \\
\hline 3 & The secret ownership of the product formulation & 0 & 20 & 3 & 32 & 15 & 85 & 45 & 76.92 \\
\hline \multirow[t]{2}{*}{4} & The advantages of the product offered compared to competitors & 0 & 0 & 0 & 21 & 16 & 76 & 76 & 87.78 \\
\hline & Total Average & & & & & & & & 84.58 \\
\hline \multirow[t]{2}{*}{ No } & Indicator & \multicolumn{7}{|c|}{ Organizational Capital Index } & Index \\
\hline & & 1 & 2 & 3 & 4 & 5 & 6 & 7 & \\
\hline 1 & Number of HR outside technical workers & 0 & 5 & 15 & 28 & 16 & 122 & 14 & 76.92 \\
\hline 2 & Business experience & 0 & 2 & 18 & 10 & 23 & 91 & 58 & 82.78 \\
\hline 3 & Performance allowances & 0 & 2 & 4 & 17 & 22 & 150 & 27 & 82.21 \\
\hline 4 & Employee system & 1 & 1 & 4 & 24 & 24 & 137 & 9 & 79.71 \\
\hline 5 & Formal education experience & 1 & 1 & 14 & 72 & 37 & 72 & 4 & 68.35 \\
\hline \multirow[t]{2}{*}{6} & Non-formal education experience & 0 & 5 & 13 & 77 & 45 & 55 & 5 & 67.64 \\
\hline & Total Average & & & & & & & & 76.27 \\
\hline \multirow[t]{2}{*}{ No } & Indicator & \multicolumn{7}{|c|}{ Relation Capital Index } & Index \\
\hline & & 1 & 2 & 3 & 4 & 5 & 6 & 7 & \\
\hline 1 & Marketing network ownership & 0 & 1 & 0 & 11 & 28 & 103 & 57 & 85.92 \\
\hline 2 & Network ownership with supporters & 0 & 14 & 0 & 12 & 13 & 127 & 34 & 81.5 \\
\hline 3 & Supplier network ownership & 0 & 11 & 0 & 3 & 15 & 118 & 53 & 84.85 \\
\hline 4 & Funding & 0 & 16 & 3 & 13 & 20 & 104 & 44 & 80.35 \\
\hline \multirow[t]{3}{*}{5} & The habit of sharing business problem among employees & 0 & 1 & 0 & 14 & 22 & 109 & 54 & 85.71 \\
\hline & Total Average & & & & & & & & 83.67 \\
\hline & Intangible Asset Index & & & & & & & & 81.51 \\
\hline \multirow[t]{2}{*}{ No } & Indicator & \multicolumn{7}{|c|}{ Innovation Orientation Index } & Index \\
\hline & & 1 & 2 & 3 & 4 & 5 & 6 & 7 & \\
\hline 1 & New products introduced & 0 & 0 & 0 & 9 & 13 & 131 & 47 & 86.85 \\
\hline 2 & Imitation products introduced & 27 & 50 & 14 & 47 & 16 & 31 & 15 & 52 \\
\hline 3 & Modification of existing products & 0 & 0 & 6 & 21 & 13 & 96 & 64 & 85.07 \\
\hline 4 & Environmentally friendly products & 0 & 0 & 0 & 19 & 17 & 112 & 52 & 85.5 \\
\hline \multirow[t]{3}{*}{5} & Use of new technique in the production & 0 & 4 & 12 & 38 & 23 & 102 & 21 & 76.42 \\
\hline & Total Average & 0 & 0 & 0 & 9 & 13 & 131 & 47 & 86.85 \\
\hline & Strategic Orientation Index & & & & & & & & 77.17 \\
\hline \multirow[t]{2}{*}{ No } & Indicator & \multicolumn{7}{|c|}{ Competitive Advantage Index } & Index \\
\hline & & 1 & 2 & 3 & 4 & 5 & 6 & 7 & \\
\hline 1 & Low Cost/ Cost Leadership & 6 & 10 & 7 & 40 & 23 & 102 & 12 & 80.96 \\
\hline 2 & High Quality & 0 & 0 & 2 & 20 & 6 & 112 & 60 & 82.224 \\
\hline 3 & Differentiation & 0 & 2 & 3 & 16 & 22 & 120 & 37 & 83.488 \\
\hline 4 & Quick Response & 0 & 0 & 3 & 16 & 11 & 119 & 51 & 84.752 \\
\hline 5 & In Imitable & 0 & 4 & 4 & 55 & 35 & 69 & 33 & 86.016 \\
\hline 6 & Unsubstituted & 0 & 9 & 5 & 57 & 26 & 72 & 31 & 87.28 \\
\hline 7 & The company have been known & 1 & 6 & 0 & 18 & 18 & 130 & 27 & 88.544 \\
\hline 8 & The product has been known & 0 & 4 & 2 & 29 & 22 & 126 & 17 & 89.808 \\
\hline & Total Average & & & & & & & & 85.38 \\
\hline
\end{tabular}

From Table 1, it can be explained that the index on all variables showed a high interpretation because the index is more significant than 71.68 .

a. Data analysis
Data processing techniques using the SEM method based on Partial Least Square (PLS) require two stages to assess a research model [34]. The stages are as follows:

a. Outer Model / Measurement model 
The outer model is intended to evaluate how the relationship between indicators and the variables they measure. This model includes three parameters used, namely convergent validity, disk validity, and reliability.

\subsection{Convergent Validity Test}

In this test, the authors used criteria by Solihin and Ratmono [35] as follow:
1. Loading factor $>0.7$ indicators were used, loading factor 0.4 to 0.7 indicators were considered, and loading factor $<0.4$ indicators was not used

2. P-value $<0.05$ from results of the analysis using SEM-PLS 3.0 obtained the loading factor and P-value as shown in Table 2:

The results of the analysis using SEM-PLS 3.0 obtained the loading factor and P-value as shown in Table 2:

Table 2. Outer Loading (Convergen Validity)

\begin{tabular}{|c|c|c|c|c|}
\hline \multirow{2}{*}{ Item / Indicator } & \multicolumn{2}{|c|}{ Early Model } & \multicolumn{2}{|c|}{ After Modification } \\
\hline & Loading Factor & P value & Loading Factor & Loading Factor \\
\hline TECH-CAP.1 & 0.729 & $<0.001$ & 0.729 & $<0.001$ \\
\hline TECH-CAP.2 & 0.814 & $<0.001$ & 0.814 & $<0.001$ \\
\hline TECH-CAP.3 & 0.439 & $<0.001$ & 0.439 & $<0.001$ \\
\hline TECH-CAP. 4 & 0.700 & $<0.001$ & 0.700 & $<0.001$ \\
\hline ORGS-CAP.1 & 0.729 & $<0.001$ & 0.729 & $<0.001$ \\
\hline ORGS-CAP. 2 & 0.512 & $<0.001$ & 0.512 & $<0.001$ \\
\hline ORGS-CAP.3 & 0.661 & $<0.001$ & 0.661 & $<0.001$ \\
\hline ORGS-CAP.4 & 0.782 & $<0.001$ & 0.782 & $<0.001$ \\
\hline ORGS-CAP.5 & 0.557 & $<0.001$ & 0.557 & $<0.001$ \\
\hline ORGS-CAP.6 & 0.239 & $<0.001$ & 0.239 & $<0.001$ \\
\hline REL-CAP.1 & 0.401 & $<0.001$ & 0.401 & $<0.001$ \\
\hline REL-CAP.2 & 0.853 & $<0.001$ & 0.853 & $<0.001$ \\
\hline REL-CAP.3 & 0.872 & $<0.001$ & 0.872 & $<0.001$ \\
\hline REL-CAP.4 & 0.846 & $<0.001$ & 0.846 & $<0.001$ \\
\hline REL-CAP.5 & 0.286 & $<0.001$ & 0.286 & $<0.001$ \\
\hline INOV-ORI.1 & 0.460 & $<0.001$ & 0.460 & $<0.001$ \\
\hline INOV-ORI.2 & 0.382 & $<0.001$ & 0.382 & $<0.001$ \\
\hline INOV-ORI.3 & 0.548 & $<0.001$ & 0.548 & $<0.001$ \\
\hline INOV-ORI.4 & 0.783 & $<0.001$ & 0.783 & $<0.001$ \\
\hline INOV-ORI.5 & 0.699 & $<0.001$ & 0.699 & $<0.001$ \\
\hline COMP-ADV.1 & 0.358 & $<0.001$ & 0.358 & $<0.001$ \\
\hline COMP-ADV.2 & 0.597 & $<0.001$ & 0.597 & $<0.001$ \\
\hline COMP-ADV. 3 & 0.609 & $<0.001$ & 0.609 & $<0.001$ \\
\hline COMP-ADV.4 & 0.620 & $<0.001$ & 0.620 & $<0.001$ \\
\hline COMP-ADV.5 & 0.742 & $<0.001$ & 0.742 & $<0.001$ \\
\hline COMP-ADV.6 & 0.725 & $<0.001$ & 0.725 & $<0.001$ \\
\hline COMP-ADV.7 & 0.530 & $<0.001$ & 0.530 & $<0.001$ \\
\hline COMP-ADV.8 & 0.508 & $<0.001$ & 0.508 & $<0.001$ \\
\hline
\end{tabular}

Note:

TECH-CAP: Technological Capital ORGS-CAP: Organizational Capital REL-CAP: Relation Capital INOV-ORI: Innovation orientation COMP-ADV: Competitive advantage INT-ASST: Intangible Asset 
Based on the criteria and the results in the loading table, these factors indicate that all 28 indicators/item instruments used in this study are included in the valid categories.

\subsection{Discriminant Validity Test}

In the discriminant validity test using criteria [35], the validity test is intended to test whether the indicators used are sufficiently valid in contributing to $\mathrm{R} 2$,

\subsection{The Criteria Used in This Validity Test Are:}

AVE square root value $>$ correlation value between variables or, Correlation value in red $>$ other correlation values in one column. The results of the analysis using SEM-PLS 3.0 obtained AVE square root values as in Table 3.

Based on the criteria and the results in the table above, all indicators used to measure variables meet valid discriminant criteria.

\subsection{Construction Reliability Test}

Criteria used in the reliability test are from Sholihin and Ratmono [35]:
1. Composite coefficient of reliability $>0.7$

2. Cronbach's alpha coefficient $>0.7$

The results of the analysis using SEM-PLS 3.0 obtained composite reliability and Cronbach; $s$ alpha coefficients as in the Table 4.

Based on the criteria and results in the table above it shows that all indicators used to measure variables meet reliable criteria.

\subsubsection{Inner Model (Structural Model)}

Structural models are used to examine the relationship/influence between latent constructs and assess these relationships' level. Some tests for structural models include: test the suitability of the model and test the hypothesis.

\subsubsection{Model Conformity Test}

Model fit and quality indices

Average path coefficient $(\mathrm{APC})=0.352, \mathrm{P}<0.001$

Average adjusted R-squared (AARS) $=0.650, \mathrm{P}<0.001$

Average block VIF $(\mathrm{AVIF})=1.425$, acceptable if $<=5$, ideally $<=3.3$

The results of the analysis show that the model in this study is appropriate. (See Figure 1).

Table 3. Correlations among l.vs. With sq. rts. Of AVEs

\begin{tabular}{ccccccc}
\hline & TECH-CAP & ORGS-CAP & REL-CAP & INOV-ORI & COMP-ADV & INT-ASST \\
\hline TECH-CAP & $\mathbf{0 . 6 8 5}$ & 0.537 & 0.259 & 0.338 & 0.351 & 0.343 \\
ORGS- CAP & 0.537 & $\mathbf{0 . 6 6 0}$ & 0.376 & 0.208 & 0.793 \\
REL- CAP & 0.259 & 0.376 & $\mathbf{0 . 7 7 4}$ & 0.149 & 0.236 & 0.851 \\
INOV-ORI & 0.338 & 0.208 & 0.149 & $\mathbf{0 . 6 5 1}$ & 0.484 & 0.663 \\
COMP-ADV & 0.351 & 0.343 & 0.236 & 0.484 & $\mathbf{0 . 6 2 9}$ & 0.303 \\
INT-ASST & 0.793 & 0.851 & 0.663 & 0.303 & 0.406 & 0.406 \\
\hline
\end{tabular}

Note: Square roots of average variances extracted (AVEs) shown on diagonal.

Table 4. Composite reliability coefficients dan Cronbach's alpha coefficients

\begin{tabular}{cccccc}
\hline TECH-CAP & ORGS- CAP & REL-CAP & INOV-ORI & INT-ASST & COMP-ADV \\
\hline 0.772 & 0.791 & 0.847 & 0.739 & 0.815 & 0.819 \\
\hline TECH-CAP & ORGS- CAP & REL- CAP & INOV-ORI & INT-ASST & COMP-ADV \\
\hline 0.607 & 0.668 & 0.750 & 0.532 & 0.658 & 0.741 \\
\hline
\end{tabular}




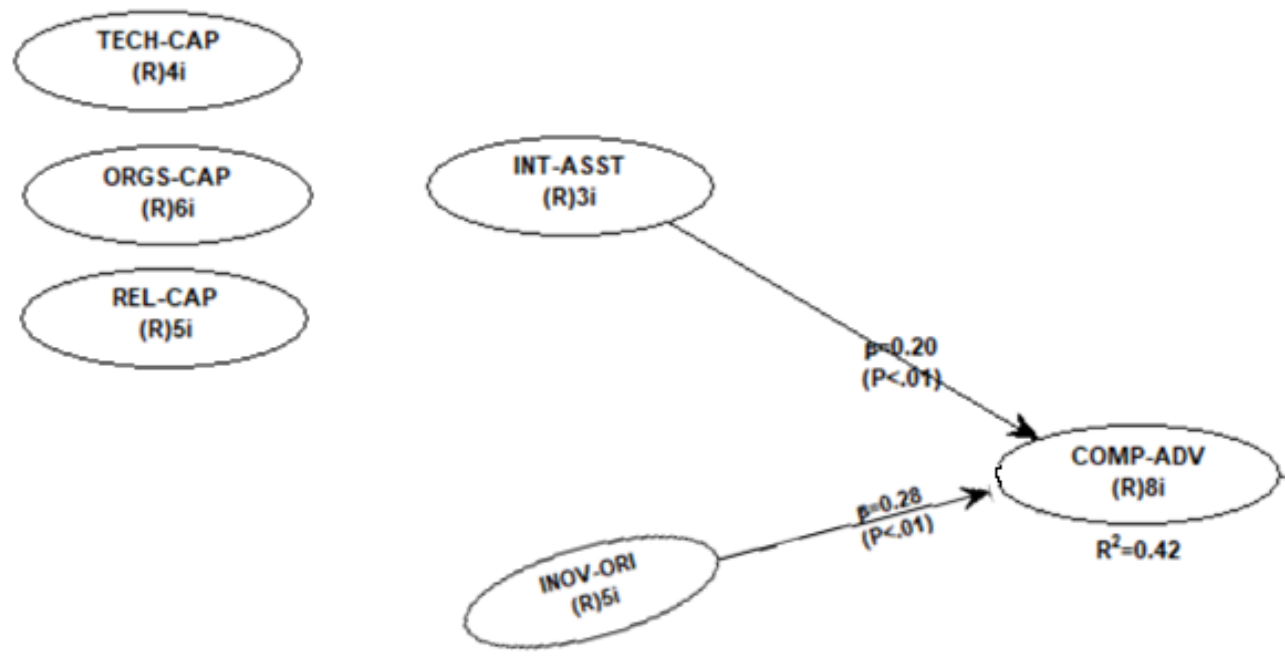

Figure 1. SEM Analysis Diagram (With parameter value)

Table 5. Path coefficients, P-Value \& Effect Size

\begin{tabular}{ccc}
\hline Coefficients & $\begin{array}{c}\text { Independent } \\
\text { Variable }\end{array}$ & $\begin{array}{c}\text { Dependent Variable } \\
\text { COMP-ADV }\end{array}$ \\
\hline $\begin{array}{c}\text { Path } \\
\text { Coefficients }\end{array}$ & INT-ASST & 0.20 \\
$(\beta)$ & INOV-ORI & 0.28 \\
P-value & INT-ASST & $<0.001$ \\
& INOV-ORI & $<0.001$ \\
Effect Size & INT-ASST & 0.089 \\
& INOV-ORI & 0.140 \\
\hline
\end{tabular}

Table 5 can be explained as follows:

Hypothesis testing 1: Intangible assets have a positive effect on competitive advantage

Obtained indices values: Path coefficient $(\beta)=0.20, \mathrm{P}$ value $<0.001(<\alpha=0.05)$, Effect Size $(\mathrm{ES})=0.089$

- $\mathrm{ES}<0.02$ : no effect

- $0.02<\mathrm{ES}<0.15$ : level of influence is weak

- $0.15<\mathrm{ES}<0.35$ : moderate level of influence

- $\mathrm{ES}>0.35$ : strong influence

These results indicate that intangible assets have a significant positive effect on competitive advantage with $\beta$ $=0.20$, and the level of influence is weak.

Hypothesis testing 2: Innovation orientation has a positive effect on competitive advantage

Obtained indices values: Path coefficient $(\beta)=0.28, \mathrm{P}$ value $<0.001(<\alpha=0.05)$, Effect Size $(\mathrm{ES})=0.140$. These results indicate that the Innovation Orientation has a significant positive effect on competitive advantage with $\beta$ $=0.28$, and the level of influence is Weak.

\section{Multiple Regression Equations}

Based on the diagram above, the regression function can be derived as follows:

$$
\begin{gathered}
\varnothing \mathrm{Y}_{1}=0.20 \mathrm{X}_{1}+0.28 \mathrm{X}_{2}+0.32 \mathrm{X}_{3} \text {, with } \mathrm{R} 2=0.42 \\
\varnothing \mathrm{Y}_{2}=0.46 \mathrm{Y}_{1} \text {, with } \mathrm{R} 2=0.21
\end{gathered}
$$

The two regression functions mentioned above can be interpreted as follows:

$\varnothing$ The greater the intangible assets, the stronger the level of competitive advantage $(\beta=0.20)$

$\varnothing$ The higher the level of innovation, the stronger the group of competitive advantage $(\beta=0.28)$ 
Table 6. Labor Productivity in Central Java

\begin{tabular}{cccccc}
\hline Year & $\begin{array}{c}\text { Number of Workers } \\
\text { (People) }\end{array}$ & $\begin{array}{c}\text { GDRP } \\
\text { (Million IDR) }\end{array}$ & $\begin{array}{c}\text { Growth } \\
(\mathbf{\%})\end{array}$ & $\begin{array}{c}\text { Labor Productivity } \\
\text { (Million IDR per Worker) }\end{array}$ & $\begin{array}{c}\text { Growth } \\
\text { (\%) }\end{array}$ \\
\hline 2011 & $15,822,765$ & $656,268,130$ & 5.04 & 41.48 & 5.21 \\
2012 & $16,531,395$ & $691,343,116$ & 5.07 & 41.82 & 0.83 \\
2013 & $16,469,960$ & $726,655,118$ & 4.86 & 44.12 & 5.50 \\
2014 & $16,550,682$ & $764,959,151$ & 5.01 & 46.22 & 4.76 \\
2015 & $16,435,142$ & $806,765,092$ & 5.18 & 49.09 & 6.21 \\
2016 & $16,511,136$ & $849,099,355$ & 4.99 & 51.43 & 4.76 \\
2017 & $17,186,674$ & $893,750,296$ & 5.00 & 52.00 & 54.12 \\
2018 & $17,245,548$ & $941,164,119$ & 5.04 & 54 & 4.95 \\
2019 & $17,441,153$ & $992,105,788$ & 5.13 & 56.88 & 4.23 \\
\hline
\end{tabular}

Table 6 shows that even though labor productivity in Central Java experienced an overall rise throughout the period, the growth tended to drop. This might be due to the relatively slow growth in GDRP. Although the number of workers had an increasing trend, if the increase in GDP is not significant. It can be inferred that the efficiency of workers in Central Java is relatively low. This is closely related to human capital, mainly education. Mean years of schooling (MYS) in Central Java have been quiet, at least until the end of 2019. On average, citizens in Central Java complete just elementary school, shown in Table 7, where the MYS only ranged between 6.7 and 7.7 years. The expected years of schooling (EYS) have also been ranging from 11 to 13 years, which is still below post-school level.

Table 7. Expected Years of Schooling (EYS) and Mean Years of Schooling (MYS) in Central Java

\begin{tabular}{lll}
\hline Year & EYS & MYS \\
\hline 2011 & 11.18 & 6.74 \\
2012 & 11.39 & 6.77 \\
2013 & 11.89 & 6.80 \\
2014 & 12.17 & 6.93 \\
2015 & 12.38 & 7.03 \\
2016 & 12.45 & 7.15 \\
2017 & 12.57 & 7.27 \\
2018 & 12.63 & 7.35 \\
2019 & 12.68 & 7.53 \\
2020 & 12.70 & 7.69 \\
\hline
\end{tabular}

Labor-augmenting technological progress can occur when there are improvements in health and education. However, when education level is low, it can lead to workers being inefficient, hence the scarcity of innovation. This can eventually lower the competitive advantage of companies because competitiveness is closely related to innovation. SMEs, in Central Java, in particular, rely mostly on workers as they are labor-intensive rather than capital-intensive. If any of their workers is not highly educated, SMEs would not gain competitive advantage.

\section{Discussion}

Based on the inferential statistical analysis results, innovation is known to have a significant impact on the competitive advantage. According to Damanpour [36], invention is the development of facilities, systems, legislation, products or services, a new technological manufacturing process, a new system or management structure, or a news organization's implementation plan. When paired with a succinct analysis of the outcomes, the contribution of creativity to the competitive advantage indicates that the indicators have been deemed to have the largest or most important contribution, since the innovation component is a calculation of technical innovation. This study shows that in Malang and Pasuruan, Indonesia, entrepreneurs and managers of small and medium-sized embroideries need to expand or develop in terms of products.

These results extend the work suggested by Dewi [37] to the assumption that there is a strong and important correlation between innovation and bersain excellence. Suliyanto [38] observed that learning orientation has a positive effect on technical innovation and managerial progress and that technical innovation has a positive effect on productivity. This correlation is likely because of its inherent nature. Though competition has become fiercer, accessing the means of doing business has become more comfortable [39].

\section{Conclusions}

This study aims to analyze the effect of Intangible Assets and Innovation Orientation on Competitive Advantages that impact the performance of Batik SME. To explore the relationship between these variables, this study uses Partial Least Square (PLS). Based on the 
analysis and discussion in the previous section, the following conclusions can be drawn:

1. The first hypothesis test results show a direct and positive relationship between Intangible Assets and the Competitive Advantages of Batik SME. This means that the better Intangible Assets will improve the Batik SME Competitive Advantage.

2. The second hypothesis test results show a direct and positive relationship between Innovation Orientation and Competitive Advantage. This means that the Innovation Orientation owned by Batik SME will increase the Competitive Advantage of Batik SME.

\section{REFERENCES}

[1] Poncin, I., Mimoun, M.S.B., "The Impact of E-Atmospherics on Physical Stores," J. Retail. Consum. Serv, vol. 21, no. 5, pp. 851-859, 2014. DOI: 10.1016/j.jretconser.2014.02.013

[2] Pantano, E, "Innovation Drivers in Retail Industry,". Int. J. Inf. Manag, vol. 34, no 3, pp. 344-350, 2014. DOI: 10.1016/j.ijinfomgt.2014.03.002

[3] Venugopalan, S., Rai, V., "Topic-Based Classification and Pattern Identification in Patents," Technol. Forecast. Soc. Change, vol. 94, no. May, pp. 236-250, 2015. DOI: 10.1016/j.techfore.2014.10.006

[4] Han, K., Shin, J., "A Systematic Way of Identifying and Forecasting Technological Reverse Salient Using QFD, Bibliometrics, and Trend Impact Analysis: a Carbon Nanotube Biosensor Case," Technovation, vol. 34, no. 9, pp. 559-570, 2014. DOI: 10.1016/j.technovation.2014.05.009

[5] Evanschitzky, H., Iyer, G.R., Kenning, P., Schutte, R., "Consumer Trial, Continuous Use, and Economic Benefits of a Retail Service Innovation: the Case of the Personal Shopping Assistant," J. Prod. Innov. Manag, vol 31, no 3, pp. 459-475, 2015. DOI: 10.1111/jpim.12241

[6] Demirkan, H., Spohrer, J., "Developing a Framework to Improve Virtual Shopping in Digital Malls with Intelligent Self-service Systems," J. Retail. Consum. Serv. vol. 21, no 5, pp. $860-868, \quad 2014$ DOI: 10.1016/j.jretconser.2014.02.012

[7] Tsai, M.C., Lee, W., Wu, H.C., "Determinants of RFID Adoption Intention: Evidence from Taiwanese Retail Chains," Inf. Manag, vol. 47, no. 5-6, pp. 255-261, 2010. DOI: $10.1016 /$ j.im.2010.05.001

[8] Altuntas, S., Dereli, T., Kusiak, A., "Forecasting Technology Success Based on Patent Data," Technol. Forecast. Soc. Change, vol. 96 no. July, pp. 202-214, 2015. DOI: $10.1016 /$ j.techfore.2015.03.011

[9] Barros, H.M., "Exploring the Use of Patents in a Weak Institutional Environment: the Effects of Innovation Partnerships, Firm Ownership, and New Management Practices," Technovation, vol. 45-46, no. November-December, pp. 63-77, 2015. DOI: 10.1016/j.tec hnovation.2015.05.003
[10] Lee, C., Jeon, J., Park, Y., "Monitoring Trends of Technological Changes Based on The Dynamic Patent Lattice: a Modified Formal Concepts Analysis Approach," Technol. Forecast. Soc. Change, vol. 78, no. 4, pp. 690-702, 2011. DOI: $10.1016 /$ j.techfore. 2010.11 .010

[11] Dababneh, R. \& Tukan, F., "Booklet of Standardized Small and Medium Enterprises Definition-2007," A publication of USAID, 2007. https://www.abj.org.jo/echobusv3.0/systema ssets/booklet $\% 20$ of $\% 20$ standardized $\% 20$ small $\% 20$ and $\% 20$ medium $\% 20$ enterprise $\% 20$ definition.pdf

[12] Scott, M., \& Bruce, R., "Five Stages of Growth in Small Business," Long Range Planning, vol. 20, no. 3, pp. 45-52, 1987.

https://hbr.org/1983/05/the-five-stages-of-small-business-gr owth

[13] Nweze, A., "Concept of Small and Medium Enterprise (SME)," The Business, 25 November. 2009

[14] Porter, M. E., "Competitive Advantage: Creating and Sustaining Superior Performance," New York: Free Press. 1985

[15] Sigalas, C., \& Economou, V. P., "Revisiting the Concept of Competitive Advantage: Problems and Fallacies Arising from Its Conceptualization," Journal of Strategy and Management, vol., 6 no. 1, pp. 61-80, 2013. DOI: $10.1108 / 17554251311296567$

[16] Bosse, D. A., Philips, R. A., \& Harrison, J. S., "Stakeholders, Reciprocity and Firm Performance," Strategic Management Journal, vol. 30, no. 4, pp. 447-456, 2009. DOI: $10.1002 /$ smj. 743

[17] Caves, R. E., \& Porter, M. E., "From Entry Barriers to Mobility Barriers: Conjectural Decisions and Contrived Deterrence to New Competition," Quarterly Journal of Economics, vol. 91 no. 2, pp. 241-261, 1977. DOI: $10.2307 / 1885416$

[18] Peteraf, M. A., "The Cornerstones of Competitive Advantage: A Resource-based View," Strategic Management Journal, vol. 14 no. 3, pp.179-91, 1993. DOI: https://www.jstor.org/stable/2486921

[19] Rao, P., \& Holt, D., "Do Green Supply Chains Lead to Competitiveness and Economic Performance?," International Journal of Operations and Production Management, vol. 25 no. 9, pp. 898-916, 2005. DOI: $10.1108 / 01443570510613956$

[20] Marr, B. \& Chatzkel, J., "Intellectual Capital at The Crossroads," Journal of Intellectual Capital, vol. 5 no.2, pp. 224-229, 2004. DOI: 10.1108/14691930410533650

[21] Epstein, B.J. and Mirza, A.A,. "Interpretation and Application of International Accounting and Financial Reporting Standard,” Wiley, New York, NY. 2005.

[22] Johanson, U., Eklov, G., Holmgren, M. \& Martensson, M., "Human Resource Costing and Accounting Versus the Balanced Scorecard: A Literature Survey of Experience with The Concepts," Stockholm: School of Business, Stockholm University, Stockholm. 1998

[23] Lev B., "Intangibles: Management, Measurement, and Reporting," Washington: The Brookings Institution. 2001

[24] Andriessen, D., "Making Sense of Intellectual Capital: 
Designing a Method for the Valuation of Intangibles," Elsevier Butterworth-Heinemann, Oxford. 2004

[25] Kujansivu, P., Lönnqvist, A., "Investigating The Value and Efficiency of Intellectual Capital," Journal of Intellectual Capital, vol. 8 no. 2, pp. 272-87, 2007. DOI: $10.1108 / 14691930710742844$

[26] Woschke T, Haase H \& Kratzer J., "Resource Scarcity in SMEs: Effects on Incremental and Radical Innovations," Management Research Review, vol. 40, no. 2, pp. 195-217, 2017. DOI: 10.1108/MRR-10-2015-0239

[27] Oke A. Burke G. \& Myers A. "Innovation Types and Performance in Growing UK SMEs," International Journal of Operations \& Production Management, vol. 27, no. 7, pp. 735-753, 2007. DOI: 10.1108/01443570710756974

[28] Kammerlander N, Burger D, Fust A, et al. "Exploration and Exploitation in Established Small and Medium-sized Enterprises: The Effect of CEOs' Regulatory Focus," Journal of Business Venturing, vol. 30, no. 4, pp. 582-602, 2015. DOI: $10.1016 /$ j.jbusvent.2014.09.004

[29] McDermott CM \& Prajogo D.I., "Service Innovation and Performance in SMEs," International Journal of Operations and Production Management," vol. 32, no. 2, pp. 216-237, 2012. DOI: $10.1108 / 01443571211208632$

[30] Voss G.B. \& Voss Z.G., "Strategic Ambidexterity in Small and Medium-sized Enterprises: Implementing Exploration and Exploitation in Product and Market Domains," Organization Science, vol. 24, no. 5, pp. 1459-1477, 2013. DOI: $10.1287 /$ orsc. 1120.0790

[31] Sugiyono, "Metode Penelitian Pendidikan Pendekatan Kuantitatif, Kualitatif, dan R\&D [Educational Research Methods with Quantitative Approaches, Qualitative, and R \& D]," Bandung: Alfabeta. 2010

[32] Hair, J. F., Black, W. C., Babin, B. J., \& Anderson, R. E., "Multivariate Data Analysis," Seven ${ }^{\text {th }}$ ed, Upper Saddle
River, NJ Prentice Hall: Pearson. 2010

[33] Ferdinand A., "Metode Penelitian Manajemen, [Method of Management Research]" Semarang: Badan. Penerbit Universitas Diponegoro. 2006

[34] Ghozali I., "Structural Equation Modelling Metode Alternatif dengan Partial Least Square," Semarang: Universitas Diponegoro. 2006 https://www.researchgate.net/publication/289674653_Struc tural Equation_Modeling Metode Alternatif_dengan_Parti al_Least_Squares_PLS\#fullTextFileContent

[35] Solihin, M., Ratmono, D., "Analisis SEM-PLS Dengan WarpPLS 3.0 Untuk Hubungan Nonlinier Dalam Penelitian Sosial dan Bisnis," Yogyakarta : Andi. 2013

[36] Damanpour F., "Organizational Innovation: a Meta-analysis of Effects of Determinants and Moderators," The Academy of Management Journal, vol. 34, no. 3, pp. 555-590, 1991. DOI: $10.2307 / 256406$

[37] Dewi, S.B., "Analisis pengaruh orientasi pasar dan inovasi produk Terhadap keunggulan bersaing Untuk meningkatkan kinerja pemasaran (Studi pada Industri Batik di Kota dan Kabupaten Pekalongan)[Analysis of the influence of market orientation and product innovation on competitive advantage to improve marketing performance (Studies on the Batik Industry in the City and District of Pekalongan)]," Tesis, Program Studi Magister Manajemen Universitas Diponegoro. 2006 http://eprints.undip.ac.id/15810/1/Sensi Tribuana_Dewi.pdf

[38] Suliyanto, "The Effect of Orientation Learning on Competitive Advantage through Innovation: Study on Small and Medium Enterprises," Business and Management Review, vol. 1, no. 7, pp. 28-36, 2011.http://www.business journalz.org/articlepdf/BMR_1701_a.pdf

[39] Dutta, S.K., "Intangible assets as a source of competitive advantage, Effective Executive," 2008. accessed 27 January 2021, from https://ssrn.com/abstract $=1885266$ 